\title{
PELAKSANAAN PROGRAM REHABILITASI SOSIAL BAGI GELANDANGAN DAN PENGEMIS DI BALAI REHABILITASI SOSIAL GELANDANGAN DAN PENGEMIS DI PULAU JAWA
}

\author{
Eltiga Angga Putra Sihombing \\ Politeknik Kesejahteraan Sosial Bandung, Eltiganggaps3@gmail.com \\ Dwi Yuliani, M.Si, Ph.D \\ Politeknik Kesejahteraan Sosial Bandung, dwi_stks@yahoo.co.id \\ Dra. Windriyanti, MP \\ Politeknik Kesejahteraan Sosial Bandung, windrystks@gmail.com
}

\begin{abstract}
This research aims to determine the implementation of a social rehabilitation program for homeless people and beggars at the Social Rehabilitation Center for Homeless and Beggars in Java. The method used in this research is secondary data analysis. The data source used in this research was six reports related to social rehabilitation programs in five social rehabilitation centers for homeless and beggars in Java and standard operating procedure (SOP) data from each of these centers. The data collection technique used in this research is the study of secondary data documentation. The data validity checking technique uses credibility test, dependability test, and data validity test. Secondary data analysis was carried out through the process of data reduction, data presentation, and conclusion drawing. The implementation of the social rehabilitation program can be examined into four aspects, namely; the social rehabilitation process, the type of social rehabilitation program, and supporting and inhibiting factors in the social rehabilitation program. The results showed that the social rehabilitation process at the social rehabilitation center for homeless and beggars had been implemented properly. The results also explain the types of social rehabilitation programs provided at the Social Rehabilitation Center for Homeless and Beggars. The social rehabilitation program has also been implemented and is in accordance with the needs of the WBS. In the implementation of the social rehabilitation program there are also supporting and inhibiting factors that can affect the running of the program. These factors can come from the assisted residents, the hall, or parties outside the hall. Based on the results of the research, it can be concluded that the implementation of the social rehabilitation program at the Social Rehabilitation Center for Homeless and Beggars in Java Island has been running as it should, although there are still obstacles in it.

Keywords:Implementation of the Social Rehabilitation Program; Homeless and Beggars;Social Rehabilitation Cente for Homeless and Beggars.
\end{abstract}

Abstrak
Tujuan dari penelitian ini adalah untuk mengetahui pelaksanaan program rehabilitasi
sosial bagi gelandangan dan pengemis di Balai Rehabilitasi Sosial Gelandangan dan
Pengemis di Pulau Jawa. Penelitian ini menggunakan metode analisis data sekunder.
Sumber data dalam penelitian ini terdiri dari enam laporan terkait program rehabilitasi 
sosial di lima balai rehabilitasi sosial gelandangan dan pengemis di Pulau Jawa dan data standar operasi prosedur (SOP) pelayanan dari masing-masing balai tersebut. Teknik pengumpulan data yang digunakan adalah studi dokumentasi data sekunder. Adapun teknik pemeriksaan keabsahan data menggunakan uji kredibilitas, uji dependability, dan uji validitas data. Analisis data sekunder dilakukan melalui proses reduksi data, penyajian data, dan penarikan kesimpulan. Pelaksanaan program rehabilitasi sosial dapat dikaji kedalam empat aspek yaitu; proses rehabilitasi sosial, jenis program rehabilitasi sosial, serta faktor pendukung dan penghambat dalam program rehabilitasi sosial. Hasil penelitian menunjukkan bahwa proses rehabililitasi sosial di Balai Rehabilitasi Sosial Gelandangan dan Pengemis di Pulau Jawa sudah dilaksanakan sebagaimana mestinya. Hasil penelitian juga menjelaskan tentang jenis program rehabilitasi sosial yang disediakan di Balai Rehabilitasi Sosial Gelandangan dan Pengemis di Pulau Jawa. Program rehabilitasi sosial juga sudah terlaksana dan sesuai dengan kebutuhan WBS. Dalam pelaksanaan program rehabilitasi sosial juga terdapat faktor pendukung dan penghambat yang dapat mempengaruhi berjalannya program. Faktor-faktor tersebut dapat berasal dari warga binaan, pihak balai, ataupun pihak diluar balai. Berdasarkan hasil penelitian maka dapat disimpulkan bahwa pelaksanaan program rehabilitasi sosial di Balai Rehabilitasi Sosial Gelandangan dan Pengemis di Pulau Jawa sudah berjalan sebagaimana mestinya walaupun masih terdapat hambatan di dalamnya.

Kata Kunci: Pelaksanaan Program Rehabilitasi Sosial; Gelandangan dan Pengemis; Balai Rehabilitasi Sosial Gelandangan dan Pengemis.

\section{PENDAHULUAN}

Kemiskinan menurut Badan

Perencanaan Pembangunan Nasional adalah kondisi dimana seseorang atau sekelompok orang, laki-laki dan perempuan, tidak mampu memenuhi hak-hak dasarnya untuk mempertahankan dan mengembangkan kehidupan yang bermartabat. Masalah kemiskinan merupakan permasalahan yang muncul dalam kehidupan bermasyarakat, berbangsa dan bernegara. Masalah kemiskinan juga merupakan suatu fenomena yang memiliki berbagai macam dimensi. Oleh karena begitu banyaknya dimensi yang terkandung didalamnya, hal ini mengakibatkan masalah kemiskinan menjadi objek kajian. Pada umumnya masalah kemiskinan ini ditafsirkan sebagai suatu kondisi yang tidak diinginkan oleh sebagaian besar warga masyarakat. Kemiskinan memiliki beberapa ciri umum diantaranya; Ketidakmampuan memenuhi kebutuhan konsumsi dasar (pangan, sandang, papan), ketiadaan akses terhadap kebutuhan hidup dasar lainnya (kesehatan, pendidikian, air bersih dan transportasi), Ketiadaan jaminan masa depan (karena tiadanya investasi untuk pendidikan dan keluarga). Masalah kemiskinan sudah menjadi masalah utama yang terjadi di Indonesia.

Masalah kemiskinan memunculkan masalah sosial lain seperti gelandangan dan pengemis (gepeng). Sebagai gejala sosial, masalah gelandangan dan pengemis hadir di tengah-tengah masyarakat. Secara formal pemerintah telah mengambil sikap yang jelas terhadap masalah gelandangan dan pengemis. Berbagai lembaga swasta pun telah membantu usaha pemerintah dalam menanggulangi masalah tersebut. 
Gelandangan dan pengemis merupakan bagian dari fenomena dalam masyarakat yang tidak dapat dipisahkan dari realitas kehidupan masyarakat. Dalam Undang-Undang Dasar 1945 (UUD 1945) Pasal 34 (1) menyatakan bahwa: "Fakir miskin dan anak-anak yang terlantar dipelihara oleh negara". Berdasarkan rumusan pasal tersebut bahwa negara yang berperan memelihara fakir miskin dan anakanak terlantar. Sebagai pelaksana dari Pasal 34 (1) UUD 1945 tersebut selanjutnya dikeluarkan Undang-Undang Nomor 13 tahun 2011 tentang penanganan fakir miskin. Gelandangan dan pengemis merupakan produk dari masalah kemiskinan yang terjadi di Indonesia. Dalam Permensos No 8 tahun 2012 ini dijelaskan bahwa yang dimaksud dengan gelandangan adalah orang-orang yang hidup dalam keadaan yang tidak sesuai dengan norma kehidupan yang layak dalam masyarakat setempat, serta tidak mempunyai pencaharian dan tempat tinggal yang tetap serta mengembara di tempat umum sedangkan pengemis adalah orangorang yang mendaat penghasilan memintaminta ditempat umum dengan berbagai cara dan alasan untuk mengharapkan belas kasihan orang lain. Departemen Sosial RI (2007) menyatakan juga bahwa salah satu faktor utama gelandangan dan pengemis adalah kemiskinan sehingga gelandangan dan pengemis perlu mendapatkan perlindungan sosial.

Dalam portal berita Kompas (22 Agustus 2019), Agus Gumiwang Kartasasmita sebagai menteri sosial yang menjabat mengatakan bahwa, diperkirakan masih ada sekitar 77.500 gelandangan dan pengemis di Indonesia khususnya yang tersebar di kota-kota besar. Banyak gelandangan dan pengemis yang sudah terdata untuk persebaran di Pulau Jawa (Jawa Timur, Jawa Barat, Jawa Tengah, DKI Jakarta, DI Yogyakarta, dan Banten). Menurut
BPS (Badan Pusat Statistik) Jawa Barat tahun 2018 terdapat 12.282 gelandangan dan pengemis yang tercatat di Jawa Barat. Menurut BPS (Badan Pusat Statistik) Jawa Timur tahun 2019 tercatat ada sekitar 6.738 gelandangan dan pengemis yang ada di Jawa Timur. Menurut data dari Bappeda Daerah Ibukota Yogyakarta tahun 2019, tercatat ada sekitar 344 gelandangan dan pengemis di Yogyakarta. Dalam portal berita Medcom.id (23 Agustus 2019), Daerah Khusus Ibu Kota (DKI) Jakarta mencatat ada sekitar 284 gelandangan dan pengemis di tahun 2018 sedangkan untuk Banten dan Jawa Tengah belum tercantum untuk data gelandangan dan pengemis yang terbaru dan relevan. Data ini menunjukkan bahwa banyaknya persebaran gelandangan dan pengemis di Pulau Jawa.

Pulau Jawa juga merupakan pulau dengan persebaran kota-kota besar yang digemari perantau sehingga banyak perantau baik dari luar maupun dalam pulau jawa yang merantau dengan tujuan untuk mendapat pekerjaan yang layak. Namun kenyataan tidak selalu sesuai dengan ekspetasi, sehingga banyak juga perantau yang gagal bersaing dalam mendapat pekerjaan. Hal inilah yang mendorong mereka untuk mencari pekerjaan yang lebih mudah, instan, dan tanpa keahlian salah satunya adalah gelandangan dan pengemis. Pernyataan tersebut diperkuat oleh Menteri Sosial Republik Indonesia Agus Gumiwang Kartasasmita. Dimuat dalam portal berita Antaranews.com (22 Agustus 2019) beliau mengatakan bahwa gelandangan dan pengemis muncul akibat pembangunan yang tidak merata sehigga mendorong warga miskin yang ada di pedesaan dan daerah-daerah dengan perekonomian kurang baik mengadu peruntungan ke kota-kota besar. Beliau juga mengatakan bahwa pendatang yang tidak 
mempunyai bekal pendidikan dan keterampilan yang memadai kesulitan menghadapi persaingan untuk mendapat pekerjaan dan akhirnya sebagian harus bergantung pada belas kasih orang lain. Masalah gelandangan dan pengemis juga melahirkan masalah lain seperti kerawanan sosial, pelecehan seksual, dan eksploitasi anak sehingga jika tidak ditangani akan menjadi masalah serius dan kompleks dan lebih sulit. Beliau mengatakan bahwa selain faktor ekonomi, mentalitas juga merupakan salah satu faktor masalah mengingat sebagian orang menjadikan mengemis sebagai pekerjaannya.

Faktor yang paling dominan dalam permasalahan gelandangan dan pengemis adalah ekonomi sebagai efek langsung dan terbatasnya peluang kerja di kota, rendahnya sumber daya manusia (SDM), dan kalah saing dengan warga lain. Apabila dikaji secara mendalam merebaknya gelandangan dan pengemis dapat bersumber dari dua faktor, yaitu: faktor subjektif (intern) dan faktor objektif (ekstern). Faktor subjektif erat hubungannya dengan karakter atau kepribadian dan rendahnya SDM. Karakter kepribadian antara lain terkait dengan sikap pasrah pada nasib, acuh tak acuh, dan kurang peduli pada lingkungan. Rendahnya SDM (pendidikan dan keterampilan) terkait erat dengan pendidikan yang rendah dan latar belakang status atau kondisi sosial ekonomi keluarga rendah, sehingga mereka terpaksa bekerja sebagai gelandangan dan pengemis meskipun pekerjaan tersebut belum dapat memenuhi tuntutan hidup. Faktor objektif (luar) merupakan faktor-faktor yang mempengaruhi kehidupan seseorang yang menjadi gelandangan dan pengemis. Faktor ini antara lain terbatasnya lapangan atau kesempatan kerja dan adanya tekanan pertambahan penduduk terhadap tanah di daerah asal, yang tidak diikuti oleh perkembangan kesempatan kerja sehingga mendorong mereka pergi ke kota (urbanisasi).

Masalah gelandangan dan pengemis merupakan masalah kesejahteraan sosial yang cukup besar, terlebih seperti yang sudah diuraikan bahwa gelandangan dan pengemis dapat menimbulkan masalah lain seperti pelecehan seksual, eksploitasi anak, dan sebagainya. Seperti yang dimuat dalam potal berita TribunJabar.Id (26 September 2018) dikatakan bahwa gepeng dan pengamen kerap mengganggu ketertiban umum, bahkan pengamen kerap memaksa meminta uang kepada masyarakat, ketika dalam angkutan umum atau angkot. Maka dari itu pemerintah tidak tinggal diam untuk menangani masalah tersebut. Pemerintah menyediakan lembagalembaga, balai, atau panti sosial sebagai pusat kegiatan pelayanan sosial melalui balai rehabilitasi sosial untuk gelandangan dan pengemis khususnya yang tersebar di Pulau Jawa. Balai ini bertugas untuk melaksanakan pelayanan rehabilitasi sosial penyandang masalah kesejahteraan sosial, khususnya gelandangan dan pengemis. Balai rehabilitasi sosial ini hadir sebagai lembaga pelayanan rehabilitasi sosial gelandangan dan pengemis untuk melaksanakan kegiatannya dalam membantu menyelesaikan permasalahannya serta mampu berperan dalam pembangunan, minimal untuk dirinya sendiri dan keluarganya. Rehabilitasi sosial menurut Nitimihardja merupakan upaya yang bertujuan untuk mengintegrasikan seseorang yang mengalami masalah sosial dalam kehidupan masyarakat dimana ia berada. Peraturan Menteri Sosial No 16 tahun 2019 juga menyatakan bahwa rehabilitasi sosial adalah proses refungsionalisasi dan pengembangan 
untuk memungkinkan seseorang mampu melaksanakan fungsi sosialnya secara wajar dalam kehidupan masyarakat. Sehingga dapat disimpulkan bahwa rehabilitasi sosial dapat diartikan sebagai pemulihan kembali seperti semula. Rehabilitasi sosial merupakan upaya yang ditujukan untuk mengintegrasikan kembali seseorang kedalam kehidupan masyarakat dengan cara membantunya meyesuaikan diri dengan keluarga, masyarakat, dan pekerjaan. Seseorang dapat berintegrasi dengan masyarakat apabila memiliki kemampuan fisik, mental, dan sosial serta diberikan kesempatan untuk berpartisipasi dalam masyarakat.

Program rehabilitasi sosial yang disediakan oleh balai rehabilitasi sosial gelandangan dan pengemis ini juga belum semua terlaksana dengan baik. Masih terjadi kendala dalam pelaksanaan program tersebut seperti, fasilitas yang kurang memadai hingga kurangnya partisipasi dari penerima manfaat (gelandangan dan pengemis) terhadap program rehabilitasi sosial selain itu kurangnya pemanfaatan program yang telah diberikan, sehingga ketika dilakukan terminasi banyak dari mereka (warga binaan balai) tidak mampu menerapkan hal yang diajarkan di balai dan kembali menjadi gelandangan dan pengemis. Maka dari itu peneliti ini ingin mengkaji bagaimana pelaksanaan program rehabilitasi sosial di balai rehabilitasi gelandangan dan pengemis mengingat bahwa gelandangan dan pengemis merupakan masalah yang cukup mengakar di Indonesia.

Perlu diketahui bahwa pelaksanaan program tidak memiliki aspek teoritis, karena aspek dari variabel ini ialah program itu sendiri. Setelah mempelajari dari data sekunder terkait dengan program rehabilitasi sosial maka peneliti bisa memutuskan aspek apa saja yang akan digunakan dalam rumusan masalah dalam penelitian ini. Adapun sumber data sekunder penelitian yang digunakan peneliti beserta rumusan masalahnya yaitu:

1 Rehabilitasi Sosial Bagi Gelandangan di Panti Sosial Bina Karya Sidomulyo Yogyakarta.

a Bagaimana rekrutmen gelandangan di PSBK Sidumulyo Yogyakarta?

b Bagaimana proses rehabilitasi sosial yang dilakukan oleh PSBK Sidomulyo Yogyakarta dalam menangani masalah gelandangan?

2 Program Pelayanan dan Rehabilitasi Sosiall Bagi Pengemis, Gelandangan Dan Orang Telantar di Balai Rehabilitasi Sosial Mardi Utomo Semarang.

Bagaimana program pelayanan dan rehabilitasi sosial terhadap pengemis, gelandangan, dan orang terlantar di Balai Rehabilitasi Sosial Mardi Utomo Semarang?

3 Pembinaan Pengemis, Gelandangan, dan Orang Terlantar (PGOT) di Balai Rehabilitasi Sosial Samekto Karti Pemalang.

a Bagaimana Pembinaan PGOT di Balaii Rehabilitasi Samekto Karti Pemalang?

b Faktor-faktor pendorong dan faktor penghambat berikut cara penanganan Pembinaan PGOT di Balai Rehabilitasi Sosial "Samekto Karti" Pemalang?

4 Pelayanan Sosial Bagi Gelandangan dan Pengemis di Panti Sosial Bina Karya Pangudi Luhur Bekasi.

a Bagaimana langkah-langkah pelayanan dan rehabilitasi sosial yang diberikan terhadap gelandangan dan pengemis di Panti Sosial Bina Karya Pangudi Luhur Bekasi? 
b Apa saja jenis pelayanan sosial yang diberikan terhadap gelandangan dan pengemis di Pantai Sosial Bina Karya Pangudi Luhur Bekasi?

c Faktor pendukung dan penghambat dalam langkah-langkah dan jenis pelayanan sosial diberikan terhadap gelandangan dan pengemis di Panti Sosial Bina Karya Pangudi Luhur Bekasi?

5 Jurnal Pelayanan dan Rehabilitasi Sosial terhadap Gelandangan dan Pengemis di Panti Sosial Bina Karya Pangudi Luhur Bekasi.

Bagaimana proses pelayanan dan rehabilitasi yang dilaksanakan PSBK Pangudi Luhur termasuk faktor pendukung dan penghambatnya?

6 Peran UPTD Panti Rehabilitasi Sosial Bina Karya Dalam Pemberdayaan Komunitas Gelandangan dan Pengemis.

a Bagaimana program pemberdayaan di UPTD PRSBK Cisarua Bandung Barat terhadap gelandangan dan pengemis?

b Bagaimana pelaksanaan program pemberdayaan di UPTD PRSBK Cisarua Bandung Barat terhadap gelandangan dan pengemis?

c Bagaimana faktor pendorong dan penghambat dalam pelaksanaan proses pemberdayaan di UPTD PRSBK Cisarua Bandung Barat terhadap gelandangan dan pengemis?

Berdasarkan sumber data tersebut dan menyesuaikan dengan kebutuhan penelitian, maka peneliti memutuskan untuk mengambil empat aspek yang akan diteliti dari pelaksanaan program rehabilitasi sosial yaitu: proses rehabilitasi sosial, jenis program rehabilitasi sosial, faktor pendukung serta penghambat dalam program rehabilitasi sosial.
Perlu diketahui juga bahwa peneliti tidak bisa turun langsung ke lokasi penelitian dikarenakan situasi Pandemic Covid-19. Oleh karena itu peneliti menggunakan alternatif lain yaitu melalui analisis data sekunder terkait topik penelitian yaitu pelaksanaan program rehabilitasi sosial di balai rehabilitasi sosial gelandangan dan pengemis yang dikumpulkan dari beberapa sumber data, sehingga peneliti tidak perlu untuk turun kelapangan.

Dalam pemilihan lokasi penelitian, peneliti mengganti menjadi pengambilan data sekunder dari beberapa balai rehabilitasi sosial gelandangan dan pengemis agar gambaran pelaksanaan program rehabilitasi sosial yang diperoleh lebih akurat karena kembali lagi penelitian ini merupakan analisis data sekunder yang dimana jumlah referensi sumber data cukup diperlukan. Untuk pemilihan Pulau Jawa sendiri, seperti yang sudah dijelaskan bahwa cukup banyak persebaran gelandangan dan pengemis di kota-kota besar yang sebagian besar ada di Pulau Jawa. Peneliti juga ingin mengetahui bagaimana upaya pemerintah khususnya di Pulau Jawa sebagai pusat pemerintahan dalam menangani permasalahan gelandangan dan pengemis yang semakin marak melalui balai rehabilitasi sosial gelandangan dan pengemis di Pulau Jawa.

Berdasarkan latar belakang tersebut, peneliti tertarik untuk melakukan penelitian dengan rumusan masalah yaitu "Bagaimana Pelaksanaan Program Rehabilitasi Sosial Bagi Gelandangan dan Pengemis di Balai Rehabilitasi Sosial di Pulau Jawa?" selanjutnya rumusan penelitian dijabarkan ke dalam subsub rumusan permasalahan sebagai berikut:

1. Bagaimana proses rehabilitasi sosial yang dilaksanakan di Balai Rehabilitasi Sosial Gelandangan dan Pengemis di Pulau Jawa? 
2. Bagaimana jenis program rehabilitasi sosial yang dilaksanakan di Balai Rehabilitasi Sosial Gelandangan dan Pengemis di Pulau Jawa?

3. Bagaimana faktor pendukung dalam program rehabilitasi sosial di Balai Rehabilitasi Sosial Gelandangan dan Pengemis di Pulau Jawa?

4. Bagaimana faktor penghambat dalam program rehabilitasi sosial di Balai Rehabilitasi Sosial Gelandangan dan Pengemis di Pulau Jawa?

Penelitian ini bertujuan untuk memperoleh gambaran secara komprehensif dan mendalam tentang pelaksanaan program rehabilitasi sosial bagi gelandangan dan pengemis di Balai Rehabilitasi Sosial di Pulau Jawa yang terdiri atas: proses rehabilitasi sosial yang dilaksanakan di balai, jenis program rehabilitasi sosial yang dilaksanakan di balai, serta faktor pendukung dan penghambat dalam program.

Hasil penelitian ini secara teoritis diharapkan dapat memberikan sumbangan pemikiran bagi pengembangan konsep dan praktik pekerjaan sosial dalam bidang kajian kemiskinan dan kelembagaan. Hasil penelitian ini juga dapat mempublikasikan pelaksanaan program rehabilitasi sosial dan menjadi acuan bagi pembuat kebijakan program rehabilitasi sosial dalam tinjauan konsep praktik pekerjaan sosial. Selain itu, secara praktis hasil penelitian ini dapat memberi sumbangan pemikiran pemecahan masalah pelaksanaan program rehabilitasi sosial bagi gelandangan dan pengemis di Balai Rehabilitasi Sosial Gelandangan dan Pengemis. Hasil penelitian ini diharapkan juga dapat digunakan dalam penyusunan program rehabilitasi sosial bagi gelandangan dan pengemis.

\section{METODE}

Metode yang digunakan dalam penelitian ini adalah metode analisis data sekunder. Metode ini merupakan metode penelitian yang dilakukan terhadap sumbersumber tertulis berupa literatur, buku, makalah, artikel dan karangan-karangan lain. Penulis berusaha mengupas secara konseptual terhadap pelaksanaan program rehabilitasi sosial bagi gelandangan dan pengemis di Balai Rehabilitasi Sosial di Pulau Jawa dengan cara melalui data yang ada.

Hal tersebut mengacu pada Heaton (2004:16; dinukil Andrews, et.al., 2012:12) merumuskan analisis data sekunder (ASD) itu sebagai "a research strategy which makes use of pre-existing quantitative data or pre-existing qualitative data for the purposes of investigating new questions or verifying previous studies." Jadi, analisis data sekunder, menurut Heaton, merupakan suatu strategi penelitian yang memanfaatkan data kuantiatif ataupun kualitatif yang sudah ada untuk menemukan permasalahan baru atau menguji hasil penelitian terdahulu. Sebutan strategi penelitian itu setara dengan sebutan metode penelitian.

Sumber data yang digunakan adalah sumber data sekunder. Menurut Sugiyono (2017) sumber data sekunder adalah sumber data yang didapatkan di lokasi penelitian melalui studi dokumentasi terhadap buku-buku maupun literatur. Adapun sumber data yang digunakan dalam penelitian ini adalah laporan dan jurnal penelitian yang terkait dengan program rehabilitasi sosial di balai. Peneliti juga menggunakan data standar operasional prosedur (SOP) dari setiap balai dalam penelitian ini.

Berikut adalah sumber data yang digunakan dalam penelitian ini: 
1 Laporan penelitian skripsi tentang Rehabilitasi Sosial Bagi Gelandangan di Panti Sosial Bina Karya Sidomulyo Yogyakarta dan Data Standar Operasional Prosedur (SOP) pelayanan dari balai tersebut.

2 Jurnal skripsi tentang Program Pelayanan dan Rehabilitasi Sosial Bagi Pengemis, Gelandangan dan Orang Telantar Di Balai Rehabilitasi Sosial Mardi Utomo Semarang Tahun 2011-2014 dan Data Standar Operasional Prosedur (SOP) pelayanan dari balai tersebut.

3 Laporan penelitian skripsi tentang Pembinaan Pengemis, Gelandangan, dan Orang Terlantar di Balai Rehabilitasi Sosial Samekto Karti Pemalang Data Standar Operasional Prosedur (SOP) pelayanan dari balai tersebut.

4 Laporan penelitian skripsi tentang Pelayanan Sosial Bagi Gelandangan dan Pengemis di Panti Sosial Bina Karya Pangudi Luhur Bekasi dan Data Standar Operasional Prosedur (SOP) pelayanan dari balai tersebut.

5 Jurnal penelitian tentang Pelayanan dan Rehabilitasi Sosial terhadap Gelandangan dan Pengemis di Panti Sosial Bina Karya Pangudi Luhur Bekasi.

6 Laporan penelitian skripsi tentang Peran UPTD Panti Rehabilitasi Sosial Bina Karya Dalam Pemberdayaan Komunitas Gelandangan dan Pengemis" Penelitian a.n. Alvi Rochmah Dewi dari Universitas Islam Negeri Sunan Gunung Djati Bandung.

Data-data berikut dikumpulkan melalui teknik studi dokumentasi. Adapun teknik pemeriksaan keabsahan data menggunakan uji kredibilitas, uji dependability, dan uji validitas. Analisis data sekunder dilakukan melalui proses reduksi data, penyajian data, dan penarikan kesimpulan.

Adapun langkah-langkah yang dilakukan peneliti dalam melakukan penelitian menggunakan metode analisis data sekunder adalah sebagai berikut:

1 Menetapkan (mencari-temukan) sumber data/informasi yang berkaitan dengan pelaksanaan program rehabilitasi sosial di balai rehabilitasi sosial gelandangan dan pengemis di Pulau Jawa

2 Mengumpulkan data yang sudah tersedia

3 Menormalisasikan data jika diperlukan dan memungkinkan (membuat data dari berbagai sumber sesetara mungkin "menjadi satu bentuk yang sama");

4 Menganalisis sumber data yang sudah terkumpul (misalnya menghitung, mentabulasi, memetakan data-data kuantiatif, atau membandingkan berbagai peraturan dan menelaahnya) sehingga pertanyaan dari penelitian ini dapat terjawab dengan data sekunder yang sudah terkumpul

\section{HASIL PENELITIAN}

Hasil dari penelitian yang telah dilakukan, disajikan oleh peneliti dalam bentuk tabel. Hasil tersebut memberikan gambaran ringkas dari 4 Aspek yang telah diteliti di lapangan oleh peneliti yaitu Proses Rehabilitasi Sosial,Jenis Program Rehabilitasi Sosial, Faktor Pendukung Program Rehabilitasi Sosial dan Faktor Penghambat Rehabilitasi Sosial, .Untuk gambarannya dapat dilihat sebagaimana berikut, 


\section{Proses Rehabilitasi Sosial}

Tabel 1. Proses Rehabilitasi Sosial di Balai Rehabilitasi di Pulau Jawa

\begin{tabular}{|c|c|c|c|c|c|}
\hline No & $\begin{array}{l}\text { BRSBK } \\
\text { Sidomulyo } \\
\text { Yogyakarta }\end{array}$ & $\begin{array}{l}\text { BRS Mardi } \\
\text { Utomo } \\
\text { Semarang }\end{array}$ & $\begin{array}{l}\text { BRS Samekto } \\
\text { Karti Pemalang }\end{array}$ & $\begin{array}{l}\text { BRSEGP } \\
\text { Pangudi Luhur } \\
\text { Bekasi }\end{array}$ & $\begin{array}{l}\text { PRSBK } \\
\text { Cisarua } \\
\text { Bandung } \\
\text { Barat }\end{array}$ \\
\hline 1 & $\begin{array}{l}\text { Pendekatan } \\
\text { Awal } \\
\text { a Home visit } \\
\text { b Seleksi } \\
\text { c Motivasi } \\
\text { d Asesmen } \\
\quad \text { awal }\end{array}$ & $\begin{array}{l}\text { Pendekatan } \\
\text { Awal } \\
\text { a Orientasi dan } \\
\quad \text { Konsultasi } \\
\text { b Identifikasi } \\
\text { c Motivasi } \\
\text { d Seleksi }\end{array}$ & $\begin{array}{l}\text { Pendekatan } \\
\text { Awal } \\
\text { a Orientasi dan } \\
\text { Sosialisasi } \\
\text { b Identifikasi } \\
\text { c Motivasi } \\
\text { d Seleksi }\end{array}$ & $\begin{array}{l}\text { Pendekatan Awal } \\
\text { a Sosialisasi } \\
\text { bOrientasi dan } \\
\quad \text { Konsultasi } \\
\text { c Identifikasi } \\
\text { d Motivasi } \\
\text { e Seleksi }\end{array}$ & $\begin{array}{l}\text { Pendekatan } \\
\text { Awal } \\
\text { a Studi } \\
\text { Kelayakan } \\
\text { bSeleksi } \\
\text { c Identifikasi } \\
\text { dMotivasi }\end{array}$ \\
\hline 2 & Penerimaan & $\begin{array}{l}\text { Registrasi dan } \\
\text { Pengasramaan }\end{array}$ & Penerimaan & Penerimaan & Penerimaan \\
\hline 3 & $\begin{array}{l}\text { Pengungkap } \\
\text { an dan } \\
\text { pemahaman } \\
\text { masalah } \\
\text { (assesment) }\end{array}$ & $\begin{array}{l}\text { Pengungkapan } \\
\text { dan } \\
\text { pemahaman } \\
\text { masalah } \\
(\text { assesment })\end{array}$ & $\begin{array}{l}\text { Perumusan/ } \\
\text { penentuan } \\
\text { program }\end{array}$ & $\begin{array}{l}\text { Pengungkapan } \\
\text { dan pemahaman } \\
\text { masalah } \\
\text { (assesment) }\end{array}$ & Assesment \\
\hline 4 & $\begin{array}{l}\text { Pelaksanaan } \\
\text { layanan } \\
\text { rehabilitasi } \\
\text { sosial }\end{array}$ & $\begin{array}{l}\text { Penyusunan } \\
\text { program } \\
\text { penanganan }\end{array}$ & $\begin{array}{l}\text { Pelaksanaan } \\
\text { Bimbingan dan } \\
\text { Rehabilitasi } \\
\text { Sosial }\end{array}$ & $\begin{array}{l}\text { Perencanaan } \\
\text { intervensi }\end{array}$ & $\begin{array}{l}\text { Rehabilitasi } \\
\text { Sosial }\end{array}$ \\
\hline 5 & Resosialisasi & $\begin{array}{l}\text { Pelaksanaan } \\
\text { layanan } \\
\text { Rehabilitasi } \\
\text { Sosial }\end{array}$ & Resosialisasi & Intervensi & Resosialisasi \\
\hline 6 & $\begin{array}{l}\text { Bimbingan } \\
\text { lanjut }\end{array}$ & Resosialisasi & Terminasi & Resosialisasi & Penyaluran \\
\hline 7 & Evaluasi & $\begin{array}{l}\text { Bimbingan } \\
\text { Lanjut }\end{array}$ & $\begin{array}{l}\text { Bimbingan } \\
\text { lanjut }\end{array}$ & Terminasi & $\begin{array}{l}\text { Pembinaan } \\
\text { Lanjut }\end{array}$ \\
\hline 8 & Terminasi & Terminasi & $\begin{array}{l}\text { Monitoring dan } \\
\text { Evaluasi }\end{array}$ & $\begin{array}{l}\text { Bimbingan } \\
\text { Lanjut }\end{array}$ & \\
\hline 9 & & & & $\begin{array}{l}\text { Monitoring dan } \\
\text { Evaluasi }\end{array}$ & \\
\hline
\end{tabular}

Berdasarkan tabel 1 maka diketahui tentang proses rehabilitasi sosial gelandangan dan pengemis di Balai Rehabilitasi Sosial Gelandangan dan Pengemis di Pulau Jawa. Diketahui bahwa program rehabililtasi sosial di Pulau Jawa dilakukan melalui suatu rangkaian tahapan yang terorganisir sehingga setiap tahapannya dilakukan secara sistematis dimulai dari pendekatan awal hingga terminasi. Proses yang dilakukan dalam program rehabilitasi sosial ini bertujuan untuk menolong para gelandangan dan pengemis dalam mengembalikan keberfungsian sosial mereka. Secara garis besar tiap balai dalam 
penelitian ini memiliki proses pelayanan yang relatif sama satu sama lain, walaupun dalam bentuk kegiatannya menyesuaikan dengan kondisi dan kebijakan dari masing-masing balai. Hal ini karena program rehabilitasi di balai rehabilitasi sosial gelandangan dan pengemis merupakan upaya dan wujud nyata dari pemerintah dalam menangani permasalahan gelandangan dan pengemis, sehingga kebijakan dasar yang digunakan tiap balai dalam penelitian ini merupakan kebijakan dengan sistem yang sama.

\section{Jenis Program Rehabilitasi Sosial}

Tabel 2. Jenis Program Layanan Rehabilitasi Sosial di Balai Rehabilitasi di Pulau Jawa

\begin{tabular}{|l|l|l|l|l|l|}
\hline No & $\begin{array}{l}\text { BRSBK } \\
\text { Sidomulyo } \\
\text { Yogyakarta }\end{array}$ & $\begin{array}{l}\text { BRS Mardi } \\
\text { Utomo } \\
\text { Semarang }\end{array}$ & $\begin{array}{l}\text { BRS Samekto } \\
\text { Karti Pemalang }\end{array}$ & $\begin{array}{l}\text { BRSEGP } \\
\text { Pangudi } \\
\text { Luhur Bekasi }\end{array}$ & $\begin{array}{l}\text { PRSBK Cisarua } \\
\text { Bandung Barat }\end{array}$ \\
\hline 1 & $\begin{array}{l}\text { Bimbingan } \\
\text { mental dan } \\
\text { spiritual }\end{array}$ & $\begin{array}{l}\text { Pembinaan } \\
\text { mental }\end{array}$ & $\begin{array}{l}\text { Rehabilitasi } \\
\text { Perilaku/ } \\
\text { bimbingan fisik }\end{array}$ & $\begin{array}{l}\text { Bimbingan/ } \\
\text { Terapi mental } \\
\text { Spiritual }\end{array}$ & $\begin{array}{l}\text { Bimbingan } \\
\text { mental }\end{array}$ \\
\hline 2 & $\begin{array}{l}\text { Bimbingan } \\
\text { sosial }\end{array}$ & $\begin{array}{l}\text { Bimbingan } \\
\text { agama/ } \\
\text { spiritual }\end{array}$ & $\begin{array}{l}\text { Rehabilitasi } \\
\text { karya/ } \\
\text { bimbingan } \\
\text { keterampilan }\end{array}$ & $\begin{array}{l}\text { Bimbingan/ } \\
\text { Terapi sosial } \\
\text { dan } \\
\text { psikologis }\end{array}$ & $\begin{array}{l}\text { Bimbingan } \\
\text { sosial }\end{array}$ \\
\hline 3 & $\begin{array}{l}\text { Bimbingan } \\
\text { fisik }\end{array}$ & $\begin{array}{l}\text { Bimbingan } \\
\text { sosial } \\
\text { masyarakat }\end{array}$ & $\begin{array}{l}\text { Pembinaan/ } \\
\text { rehabilitasi } \\
\text { sosial psikologi }\end{array}$ & $\begin{array}{l}\text { Bimbingan/ } \\
\text { Terapi fisik }\end{array}$ & Bimbingan fisik \\
\hline 4 & $\begin{array}{l}\text { Bimbingan } \\
\text { keterampilan } \\
\text { peningkatan } \\
\text { keterampilan }\end{array}$ & $\begin{array}{l}\text { Rimbingabilitasi } \\
\text { mental }\end{array}$ & $\begin{array}{l}\text { Bimbingan } \\
\text { keterampilan } \\
\text { kerja/ Terapi } \\
\text { vokasional }\end{array}$ & $\begin{array}{l}\text { Bimbingan } \\
\text { keterampilan }\end{array}$ \\
\hline 5 & $\begin{array}{l}\text { Bimbingan } \\
\text { konseling }\end{array}$ & $\begin{array}{l}\text { Pelayanan } \\
\text { Akomodasi }\end{array}$ & $\begin{array}{l}\text { Rehabilitasi } \\
\text { pendidikan }\end{array}$ & $\begin{array}{l}\text { Bimbingan } \\
\text { konseling }\end{array}$ & $\begin{array}{l}\text { Bimbingan } \\
\text { Konseling }\end{array}$ \\
\hline 6 & $\begin{array}{l}\text { Bimbingan } \\
\text { praktik } \\
\text { belajar kerja }\end{array}$ & & $\begin{array}{l}\text { Layanan } \\
\text { pendidikan }\end{array}$ & $\begin{array}{l}\text { Layanan } \\
\text { Pendidikan }\end{array}$ \\
\hline 7 & & $\begin{array}{l}\text { Layanan } \\
\text { rekreasi dan } \\
\text { hiburan }\end{array}$ & \\
\hline
\end{tabular}

Berdasarkan tabel 2 diketahui bahwa tiap balai rehabilitasi sosial gelandangan dan pengemis di Pulau Jawa memiliki programnya masing-masing dalam melaksanakan rehabilitasi sosial. Serupa dengan proses rehabilitasi sosial, secara garis besar tiap balai dalam penelitian ini juga memiliki jenis program pelayanan yang relatif sama satu sama lain, walaupun dalam bentuk kegiatannya akan menyesuaikan dengan kondisi dan kebijakan dari masing-masing balai. Program rehabilitasi sosial yang dilaksanakan di balai ditujukan untuk melatih klien agar mampu berintegrasi kembali di lingkungan sosialnya khususnya di keluarga dan masyarakat. Maka dari itu 
program yang dilaksanakan di balai sangat diupayakan untuk mencakup aspek-aspek kebutuhan diri klien seperti mental dan spiritual, sosial, fisik, dan keterampilan. Selain itu, pihak balai juga memperhatikan kebutuhan sandang, pangan, serta papan yang layak bagi klien selama menjalani program rehabilitas.

\section{Faktor Pendukung Program Rehabilitasi Sosial}

Tabel 3 Faktor Pendukung Program Rehabilitasi Sosial

\begin{tabular}{|l|l|l|l|}
\hline No & $\begin{array}{l}\text { BRS Samekto Karti } \\
\text { Pemalang }\end{array}$ & $\begin{array}{l}\text { BRSEGP Pangudi } \\
\text { Luhur Bekasi }\end{array}$ & $\begin{array}{l}\text { PRSBK Cisarua } \\
\text { Bandung Barat }\end{array}$ \\
\hline 1 & $\begin{array}{l}\text { Adanya kerjasama } \\
\text { lintas sektoral dengan } \\
\text { instansi yang terkait } \\
\text { dalam penanganan } \\
\text { gelandangan dan } \\
\text { pengemis }\end{array}$ & $\begin{array}{l}\text { Bantuan dari Dinas } \\
\text { Sosial setempat }\end{array}$ & $\begin{array}{l}\text { Dukungan Pemerintah } \\
\text { untuk adanya lembaga } \\
\text { sosial khusus gelandagan } \\
\text { dan pengemis }\end{array}$ \\
\hline 2 & $\begin{array}{l}\text { Adanya buku-buku } \\
\text { penunjang untuk } \\
\text { mengisi kegiatan } \\
\text { pembinaan }\end{array}$ & $\begin{array}{l}\text { Sarana prasarana yang } \\
\text { memadai }\end{array}$ & $\begin{array}{l}\text { Pegawai balai yang } \\
\text { saling membantu sama } \\
\text { lain }\end{array}$ \\
\hline 3 & $\begin{array}{l}\text { Adanya Pekerja Sosial } \\
\text { yang berkompeten }\end{array}$ & \\
\hline 4 & & $\begin{array}{l}\text { Warga binaan mampu } \\
\text { diajak bekerjasama }\end{array}$ & \\
\hline 5 & & $\begin{array}{l}\text { Koordinasi yang baik } \\
\text { antar pegawai }\end{array}$ & \\
\hline 6 & & $\begin{array}{l}\text { Memiliki instrumen } \\
\text { untuk melaksanakan } \\
\text { bimbingan lanjut }\end{array}$ & \\
\hline
\end{tabular}

Berdasarkan tabel 3 maka telah diketahui mengenai faktor-faktor pendukung dari program rehabilitasi sosial di Balai Rehabilitasi Sosial Gelandangan dan pengemis di Pulau Jawa walaupun tidak semua laporan penelitian terdahulu yang digunakan dalam penelitian ini menguraikan faktor pendukung dalam program rehabilitasi sosialnya. Meski begitu faktor-faktor yang ditemukan ini dapat menjadi tolak ukur antar balai untuk memanfaatkan faktor-faktor tersebut agar mampu dikelola dengan baik oleh masingmasing balai. Dapat dilihat juga bahwa faktor pendukung yang ditemukan antar balai juga cukup beragam yang dimana faktor-faktor tersebut datang dari berbagai pihak seperti pihak balai, organisasi yang membantu, ataupun warga binaan sosial (WBS) itu sendiri. 


\section{Faktor Penghambat Program Rehabilitasi Sosial}

Tabel 4 Faktor Penghambat Program Rehabilitasi Sosial

\begin{tabular}{|c|c|c|c|c|c|}
\hline No & $\begin{array}{l}\text { BRSBK } \\
\text { Sidomulyo } \\
\text { Yogyakarta }\end{array}$ & $\begin{array}{l}\text { BRS Mardi } \\
\text { Utomo } \\
\text { Semarang }\end{array}$ & $\begin{array}{l}\text { BRS } \\
\text { Samekto } \\
\text { Karti } \\
\text { Pemalang }\end{array}$ & $\begin{array}{l}\text { BRSEGP Pangudi } \\
\text { Luhur Bekasi }\end{array}$ & $\begin{array}{l}\text { PRSBK } \\
\text { Cisarua } \\
\text { Bandung Barat }\end{array}$ \\
\hline 1 & $\begin{array}{l}\text { Pengelolaan } \\
\text { waktu } \\
\text { kegiatan } \\
\text { yang kurang } \\
\text { baik. }\end{array}$ & $\begin{array}{l}\text { Masyarakat } \\
\text { yang } \\
\text { menganggap } \\
\text { bahwa } \\
\text { penanganan } \\
\text { masalah } \\
\text { gelandangan } \\
\text { dan pengemis } \\
\text { hanya menjadi } \\
\text { tanggung } \\
\text { jawab } \\
\text { pemerintah. }\end{array}$ & $\begin{array}{l}\text { Penerima } \\
\text { manfaat } \\
\text { malas } \\
\text { ketika } \\
\text { mengikuti } \\
\text { kegiatan. }\end{array}$ & $\begin{array}{l}\text { WBS yang } \\
\text { sering malas- } \\
\text { malasan dalam } \\
\text { mengikuti } \\
\text { kegiatan }\end{array}$ & \\
\hline 2 & $\begin{array}{l}\text { Pihak balai } \\
\text { kurang } \\
\text { mengetahui } \\
\text { minat warga } \\
\text { binaannya. }\end{array}$ & & $\begin{array}{l}\text { Sarana dan } \\
\text { prasarana } \\
\text { yang belum } \\
\text { memadai. }\end{array}$ & $\begin{array}{l}\text { Keterbatasan } \\
\text { dana dan fasilitas } \\
\text { yang belum } \\
\text { begitu lengkap }\end{array}$ & \\
\hline 3 & & & & $\begin{array}{l}\text { Waktu } \\
\text { pendidikan yang } \\
\text { dilakukan hanya } \\
6 \text { bulan, } \\
\text { sehingga dirasa } \\
\text { hasil dari proses } \\
\text { pelayanan PSBK } \\
\text { ini dirasa kurang. }\end{array}$ & \\
\hline 4 & & & & $\begin{array}{l}\text { Seringnya WBS } \\
\text { memilih jenis } \\
\text { keterampilan } \\
\text { yang tidak sesuai } \\
\text { dengan } \\
\text { kemampuannya. }\end{array}$ & \\
\hline 5 & & & & $\begin{array}{l}\text { Belum ada } \\
\text { instrumen yang } \\
\text { baku untuk } \\
\text { melakukan } \\
\text { asesmen. }\end{array}$ & \\
\hline 6 & & & & $\begin{array}{l}\text { Petugas asesmen } \\
\text { belum memiliki } \\
\text { ilmu asesmen } \\
\text { yang memadai. }\end{array}$ & \\
\hline
\end{tabular}




\begin{tabular}{|c|c|c|c|c|}
\hline 1 & 2 & 3 & 4 & 5 \\
\hline 7 & & & & $\begin{array}{l}\text { Dunia usaha yang } \\
\text { masih meragukan } \\
\text { para WBS } \\
\text { dikarenakan sikap } \\
\text { dari beberapa } \\
\text { WBS terhadap } \\
\text { pekerjaan masih } \\
\text { kurang, masih } \\
\text { malas-malasan, } \\
\text { dan setelah } \\
\text { beberapa bulan } \\
\text { bekerja sering } \\
\text { meninggalkan } \\
\text { pekerjaan tanpa } \\
\text { pamit dan } \\
\text { membawa } \\
\text { beberapa } \\
\text { peralatan kerja. }\end{array}$ \\
\hline 8 & & & & $\begin{array}{l}\text { Sertifikat dari } \\
\text { pihak balai yang } \\
\text { belum diakui. }\end{array}$ \\
\hline & & & & \\
\hline
\end{tabular}

Berdasarkan tabel 4 tersebut maka telah diketahui mengenai faktor-faktor penghambat dari program rehabilitasi sosial di Balai Rehabilitasi Sosial Gelandangan dan pengemis di lima lokasi penelitian di Pulau Jawa. Hambatan yang terjadi antar balai juga berbeda-beda. Meski begitu, hambatanhambatan yang ditemukan ini dapat dijadikan tolak ukur dan bahan evaluasi antar balai agar dapat dilakukan tindakan pencegahan dan penanganan terkait faktor penghambat yang ditemukan. Serupa dengan faktor pendukung, faktor penghambat yang terjadi dalam program rehabilitasi sosial juga dapat disebabkan oleh WBS ataupun pihak balai sebagai pelaksana dari program rehabilitasi sosial itu sendiri..

\section{PEMBAHASAN}

Pembahasan dalam penelitian ini akan mencoba menganalisis hasil penelitian yang telah didapatkan secara lanjut guna memperoleh pemahaman mendalam terhadap pelaksanaan program rehabilitasi sosial gelandangan dan pengemis di Pulau Jawa Seperti yang sudah diketahui bahwa dalam pelaksanaan program rehabilitasi sosial ada empat aspek yang dapat diidentifikasi peneliti yaitu proses rehabilitasi sosial, jenis layanan program yang dilakukan, serta faktor pendukung dan penghambat pada program rehabilitasi sosial. Adapun pembahasan hasil penelitian sebagai berikut: 


\section{Proses Rehabilitasi Sosial}

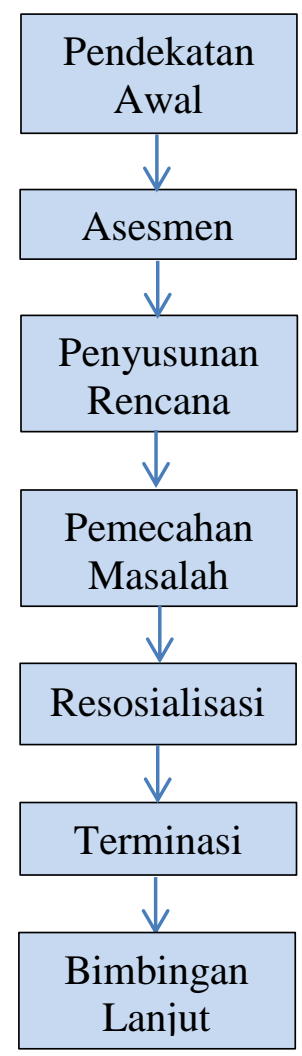

\section{a. Pendekatan Awal}

Sebagaimana yang dinyatakan dalam Dorang Luhpuri dan Rini Hartini R.A (2019) bahwa pendekatan awal merupakan proses awal rehabilitasi sosial dan didefinisikan sebagai kegiatan penyampaian informasi kepada klien, keluarga, kerabat, institusi, maupun masyarakat untuk memberi informasi layanan rehabilitasi sosial yang dapat dijangkau. Pendekatan awal juga dilakukan untuk memastikan klien dapat dilayani untuk selanjutnya dapat diregistrasi sebagai calon penerima layanan.

Berdasarkan hasil penelitian, pendekatan awal yang dilakukan oleh Balai Rehabilitasi Gelandangan dan Pengemis di Pulau Jawa dilakukan melalui beberapa kegiatan seperti sosialsasi, orientasi, konsultasi, identifikasi, dan seleksi. Pendekatan di tiap balai dilakukan untuk mendapatkan/merekrut calon penerima layanan. Dalam pelaksanaannya, proses perekrutan dapat dilakukan dengan beberapa cara seperti yang dilakukan oleh kelima balai dalam penelitian ini melalui rujukan dari LKS atau Dinas Sosial setempat. Selain dari hasil rujukan, sosialisasi dan motivasi juga dilakukan langsung ke lokasi gelandangan dan pengemis dalam mendapatkan calon penerima layanan seperti yang dilakukan oleh BRSBK Sidomulyo, BRS Mardi Utomo, dan BRS Samekto Karti.

Pendekatan awal di balai juga dilakukan dengan sosialisasi, orientasi, dan konsultasi. Kegiatan ini dilakukan untuk menyampaikan informasi tentang program rehabilitasi sosial di balai ke instansi terkait yang dapat membantu dalam pelaksanaan program guna memperoleh dukungan dan kerjasama. Kelima balai dalam penelitian ini juga melakukan identifikasi kepada gelandangan dan pengemis untuk mengenal dan memahami masalah dari calon penerima layanan, motivasi untuk menumbuhkan kesadaran dan minat gelandangan dan pengemis dalam mengikuti program rehabilitasi sosial, serta seleksi yang dilakukan untuk memilih dan menetapkan calon penerima layanan, dan proses penerimaan melalui kegiatan registrasi dan penempatan WBS dalam program rehabilitasi sosial.

Dapat disimpulkan bahwa proses pendekatan awal di Balai Rehabilitasi Sosial Gelandangan dan pengemis di Pulau Jawa yang menurut teori adalah untuk menyampaikan informasi tentang pelayanan balai, mendapatkan calon penerima layanan, dan melakukan registrasi terhadap calon penerima layanan sudah terlaksana.

\section{b.Pengungkapan dan Penanganan Masalah} (Assesment)

Sebagaimana yang dikatakan dalam 
Dorang Luhpuri dan Rini Hartini R.A (2019) bahwa asesmen dilakukan untuk menelaah dan memahami masalah yang dihadapi oleh klien. Asesmen juga dilakukan untuk mengetahui potensi dan sumber yang dapat digunakan untuk menyelesaikan masalah klien.

Berdasarkan hasil penelitian, asesmen yang dilakukan di Balai Rehabilitasi Sosial Gelandangan dan Pengemis di Pulau Jawa adalah dengan menelusuri dan menggali data klien, faktor penyebab masalah, dan kekuatan untuk membantu dirinya sendiri. Asesmen dilakukan oleh pekerja sosial dengan mengkaji aspek-aspek dari WBS seperti fisik, mental spiritual/psikologis, sosial, dan keterampilan WBS. Asesmen dilakukan melalui kegiatan case conference untuk merumuskan rencana intervensi kepada WBS.

Dapat disimpulkan bahwa proses asesmen di Balai Rehabilitasi Sosial Gelandangan dan pengemis di Pulau Jawa yang dalam teori dilakukan untuk menelaah dan memahami masalah yang dihadapi oleh klien dan mengetahui potensi serta sumber yang dapat digunakan untuk menyelesaikan masalah klien sudah terlaksana.

\section{c. Penyusunan Rencana Pemecahan Masalah}

Sebagaimana yang dikatakan dalam Dorang Luhpuri dan Rini Hartini R.A (2019) bahwa penyusunan rencana pemecahan masalah merupakan kegiatan yang dilakukan untuk menyusun rencana pemecahan masalah berdasarkan hasil asesmen. Kegiatan penyusunan rencana pemecahan masalah ini akan memberikan informasi tentang kegiatan yang akan dilakukan, oleh siapa dilakukan dan waktunya kapan. Dikatakan juga dalam Peraturan Menteri Sosial No 16 Tahun 2019 pasal 7 ayat (2) bahwa penyusunan rencana intervensi dan intervensi dengan bentuk rehabilitasi sosial dilaksanakan berdasarkan hasil asesmen pekerja sosial.

Berdasarkan hasil penelitian, penyusunan rencana pemecahan masalah (rencana intervensi) di Balai Rehabilitasi Sosial Gelandangan dan Pengemis di Pulau Jawa dilakukan dengan merumuskan rencanarencana penanganan dan menentukan jenis pelayanan yang akan didapatkan oleh WBS. Penyusunan rencana intervensi dilakukan melalui case conference/sidang kasus berdasarkan hasil dari asesmen kebutuhan dan masalah WBS yang sudah digali sebelumnya, sehingga akan tersusunnya rencana pemenuhan kebutuhan pelayanan terhadap klien.

Dapat disimpulkan bahwa proses penyusunan rencana pemecahan masalah di Balai Rehabilitasi Sosial Gelandangan dan Pengemis di Pulau Jawa yang menurut teori adalah untuk menyusun rencana pemecahan masalah berdasarkan hasil asesmen sudah terlaksana.

\section{d. Pemecahan Masalah}

Sebagaimana yang dikatakan dalam Dorang Luhpuri dan Rini Hartini R.A (2019) bahwa pemecahan masalah dilakukan sebagai pelaksana dari rencana pemecahan masalah yang telah disusun. Proses ini dilakukan dengan melaksanakan serangkaian kegiatan rehabilitasi sosial yang diperoleh klien untuk memulihkan keberfungsian sosialnya.

Berdasarkan hasil penelitian, pemecahan masalah (intervensi) di Balai Rehabilitasi Sosial Gelandangan dan Pengemis di Pulau Jawa dilakukan melalui serangkaian kegiatan program rehabilitasi sosial yang sudah disediakan oleh balai dengan tujuan untuk melatih dan memulihkan keberfungsian sosial WBS. Seperti yang sudah diketahui bahwa program kegiatan yang dilaksanakan antar balai juga cukup variatif karena menyesuaikan 
dengan kondisi dari setiap balai. Intervensi yang dilaksanakan oleh balai juga menyesuaikan pada hasil asesmen dan rencana intervensi yang telah dibuat dan meliputi aspek-aspek kebutuhan dari WBS itu sendiri khususnya dalam aspek fisik, mental dan spiritual, sosial, dan keterampilan.

Dapat disimpulkan bahwa proses pemecahan masalah di Balai Rehabilitasi Sosial Gelandangan dan Pengemis di Pulau Jawa yang menurut teori dilakukan dengan melaksanakan serangkaian kegiatan rehabilitasi sosial yang diperoleh klien untuk memulihkan keberfungsian sosialnya dan dilaksanakan berdasarkan rencana pemecahan masalah yang telah disusun sudah terlaksana.

\section{e. Resosialisasi}

Sebagaimana yang dikatakan dalam Dorang Luhpuri dan Rini Hartini R.A (2019) bahwa resosialisasi dilakukan dengan kegiatan magang sesuai bekal keterampilan yang telah diperoleh dalam layanan rehabilitasi. Kegiatan lain yang dilakukan juga berupa aktivitas bersama keluarga yang dirancang untuk mendekatkan interaksi dan relasi antara gelandangan dan pengemis dengan keluarga setelah lama berpisah.

Berdasarkan hasil penelitian, resosialisasi di Balai Rehabilitasi Sosial Gelandangan dan Pengemis di Pulau Jawa dilaksanakan dengan mempersiapkan WBS kembali kepada keluarga dan masyarakat serta mempersiapkan keluarga dan masyarakat agar mampu untuk kembali menerima WBS. Resosialisasi dilakukan melalui kegiatan magang pada sektor-sektor usaha sesuai dengan keterampilan yang diperoleh dari balai dan melakukan aktivitas bersama keluarga untuk mendekatkan kembali keluarga dengan WBS.

Dapat disimpulkan bahwa proses resosialisasi di Balai Rehabilitasi Sosial
Gelandangan dan Pengemis di Pulau Jawa yang menurut teori dilakukan melalui kegiatan magang sesuai dengan keterampilan yang diperoleh dari balai dan melakukan aktivitas bersama keluarga untuk mendekatkan kembali keluarga dengan WBS sudah terlaksana.

\section{f.Terminasi}

Sebagaimana yang dikatakan dalam Dorang Luhpuri dan Rini Hartini R.A (2019) proses terminasi merupakan kegiatan pengakhiran pelayanan karena klien telah selesai mengikuti proses rehabilitasi sosial di lembaga.

Berdasarkan hasil penelitian, terminasi di Balai Rehabilitasi Sosial Gelandangan dan Pengemis di Pulau Jawa dilakukan sebagai proses pengakhiran layanan terhadap klien. Selain sebagai proses pengakhiran kegiatan yang dilakukan dalam terminasi adalah untuk memastikan hasil evaluasi dalam tiap tahapan program rehabilitasi sosial. Proses ini juga dilakukan sebagai pemutusan hubungan secara profesional dengan WBS.

Dapat disimpulkan bahwa proses terminasi di Balai Rehabilitasi Sosial Gelandangan dan Pengemis di Pulau Jawa yang menurut teori merupakan kegiatan pengakhiran pelayanan karena klien telah selesai mengikuti proses rehabilitasi sosial sudah terlaksana.

\section{g. Bimbingan Lanjut}

Sebagaimana yang dikatakan dalam Dorang Luhpuri dan Rini Hartini R.A (2019) bahwa bimbingan lanjut merupakan kegiatan untuk memastikan klien dapat beradaptasi dengan baik. Kegiatan ini diberikan melalui pendampingan kewirausahaan, bantuan sosial kepada klien, dan menyalurkan klien ke dunia usaha.

Berdasarkan hasil penelitian, bimbingan lanjut di Balai Rehabilitasi Sosial Gelandangan dan Pengemis di Pulau Jawa 
dilakukan melalui beberapa kegiatan seperti bimbingan peningkatan kehidupan bermasyarakat dan peran serta dalam pembangunan, pemberian bantuan pengembangan usaha/ bimbingan peningkatan keterampilan, dan bimbingan pemantapan kemandirian/peningkatan usaha/kerja. Bimbingan lanjut dilakukan kepada WBS yang telah kembali ke masyarakat guna memastikan klien dapat beradaptasi dengan baik dilingkungan bermasyarakat. Diketahui juga bahwa beberapa balai mengalami kendala dalam pelaksanaan bimbingan lanjut. Seperti yang diuraikan dalam BRSBK Sidomulyo Yogyakarta yang tidak melaksanakan bimbingan lanjut dan BRSEGP Pangudi Luhur yang mengatakan bahwa bimbingan lanjut hanya dilakukan kepada sebagian kecil WBS nya. BRS Mardi Utomo Semarang juga mengemukakan bahwa proses bimbingan lanjut tidak berjalan dengan baik di balai ini. Hal ini disebabkan karena keterbatasan anggaran dan cukup sulit mengajak masyarakat untuk bekerjasama dalam melaksanakan bimbingan lanjut.

Dapat disimpulkan bahwa proses bimbingan lanjut di Balai Rehabilitasi Sosial belum terlaksana dengan baik. Hal ini dapat dilihat dari pelaksanaan bimbingan lanjut di beberapa Balai Rehabilitasi Sosial di Pulau Jawa belum terlaksana sepenuhnya.

\section{Jenis Program Rehabilitasi Sosial}

\section{a. Motivasi dan Diagnosis Psikososial/} Asesmen Kebutuhan

Sebagaimana yang dikatakan dalam Dorang Luhpuri dan Rini Hartini R.A (2019) bahwa program layanan ini dilakukan untuk menumbuhkan kemauan klien dan keluarga dalam mengikuti proses rehabilitasi sosial serta upaya untuk mengidentifikasi situasi psikososial, mengidentifikasi antara stress dan kekuatan, persepsi dan sikap tentang proses rehabilitasi, termasuk motivasinya. Mengidentifikasi pihak lain yang penting dalam kehidupan klien, serta lingkungan sekitar yang berpengaruh atau dapat digunakan sebagai sistem sumber.

Berdasarkan hasil penelitian, motivasi dan diagnosis psikososial/asesmen kebutuhan di Balai Rehabilitasi Sosial Gelandangan dan Pengemis di Pulau Jawa dilakukan melalui kegiatan pemberian motivasi kepada WBS pada proses pendekatan awal dan akan terus diberikan menyesuaikan dengan kondisi WBS selama di balai. Diagnosis psikososial dan asesmen kebutuhan juga dilakukan oleh kelima balai dalam penelitian ini melalui kegiatan asesmen awal yang dilakukan saat mengidentifikasi permasalahan serta kebutuhan WBS untuk menetapkan jenis pelayanan apa yang akan diperoleh dan akan terus di "follow up" dengan asesmen lanjut yang dilakukan dengan menyesuaikan kondisi perkembangan WBS selama dibalai. Program ini dilakukan untuk menumbuhkan kemauan klien dalam mengikuti proses rehabilitasi sosial serta upaya untuk mengidentifikasi situasi klien, pihak lain, dan lingkungan sekitar yang penting dan berpengaruh atau dapat digunakan sebagai sistem sumber bagi WBS.

Dapat disimpulkan bahwa motivasi dan diagnosis psikososial/assesmen kebutuhan di Balai Rehabilitasi Sosial Gelandangan dan Pengemis di Pulau Jawa yang menurut teori dilakukan untuk menumbuhkan kemauan klien dalam mengikuti proses rehabilitasi sosial serta upaya untuk mengidentifikasi situasi klien, pihak lain, dan lingkungan sekitar yang penting dan berpengaruh atau dapat digunakan sebagai sistem sumber bagi WBS sudah terlaksana. 


\section{b. Perawatan dan Pengasuhan}

Sebagaimana yang dikatakan dalam Dorang Luhpuri dan Rini Hartini R.A (2019) bahwa perawatan dan pengasuhan merupakan kegiatan untuk memberikan rawatan, perhatian, bimbingan dan dukungan untuk memenuhi dan mengembangkan kemampuan fisik, mental, sosial dan spiritual klien. Perawatan pengasuhan menjadi kebutuhan sehari-hari gelandangan dan pengemis agar dapat menjalani dan menikmati hari-harinya.

Berdasarkan hasil penelitian, perawatan dan pengasuhan di Balai Rehabilitasi Sosial Gelandangan dan Pengemis di Pulau Jawa dilakukan melalui pengasramaan (penyediaan tempat tinggal yang layak), penyediaan pakaian, makanan, layanan kesehatan dan kebutuhan sehari-hari lainnya. Layanan program ini dilakukan untuk memberikan rawatan, perhatian, bimbingan dan dukungan untuk memenuhi dan mengembangkan kemampuan fisik, mental, sosial dan spiritual kepada WBS agar dapat menjalani dan menikmati hari-harinya.

Dapat disimpulkan bahwa program perawatan dan pengasuhan di Balai Rehabilitasi Sosial Gelandangan dan Pengemis di Pulau Jawa yang menurut teori merupakan kegiatan untuk memberikan rawatan, perhatian, bimbingan dan dukungan untuk memenuhi dan mengembangkan kemampuan fisik, mental, sosial dan spiritual kepada WBS agar dapat menjalani dan menikmati hari-harinya sudah terlaksana tentunya dengan menyesuaikan kemampuan dan kebijakan dari masing-masing balai.

\section{c. Pelatihan Vokasional dan Pembinaan. Kewirausahaan}

Sebagaimana yang dikatakan dalam Dorang Luhpuri dan Rini Hartini R.A (2019), pelatihan vokasional merupakan kegiatan untuk memberikan pelatihan keterampilan dan kerja praktis sesuai dengan kondisi memungkinkan klien dapat melakukannya secara mandiri. Pembinaan kewirausahaan merupakan bimbingan pengembangan usaha mandiri, yang memungkinkan dikembangkan di lingkungan tempat tinggalnya.

Berdasarkan hasil penelitian, pelatihan vokasional dan pembinaan kewirausahaan di Balai Rehabilitasi Sosial Gelandangan dan Pengemis di Pulau Jawa dilakukan dengan menyediakan kelas-kelas keterampilan untuk WBS. Bimbingan keterampilan ini dilakukan untuk membekali WBS sehingga mampu menolong dirinya setelah selesai menjalani masa rehabilitasi. Selain itu, kelima balai dalam penelitian ini juga mengajarkan kewirausahaan sehingga nantinya WBS dapat mengelola usaha mereka dengan baik. Jenis keterampilan yang dilatih di Balai Rehabilitasi Sosial Gelandangan dan Pengemis dalam penelitian ini juga cukup beragam seperti keterampilan menjahit, montir motor/mobil, kerajinan tangan, dan keterampilan lainnya disesuaikan dengan kondisi dan kebijakan pada setiap balai.

Dapat disimpulkan bahwa pelatihan vokasional dan pembinaan kewirausahaan di Balai Rehabilitasi Sosial Gelandangan dan Pengemis di Pulau Jawa yang menurut teori merupakan kegiatan untuk memberikan pelatihan keterampilan dan kerja praktis serta bimbingan pengembangan usaha mandiri kepada WBS sudah terlaksana sesuai dengan jenis keterampilan yang disediakan oleh masing-masing balai.

\section{d. Bimbingan Mental dan Spiritual}

Sebagaimana yang dikatakan dalam Dorang Luhpuri dan Rini Hartini R.A (2019), bimbingan mental dan spiritual didefinisikan sebagai kegiatan untuk meningkatkan 
kemampuan gelandangan dan pengemis dalam melaksanakan ibadahnya.

Berdasarkan hasil penelitian, bimbingan mental dan spiritual di Balai Rehabilitasi Sosial Gelandangan dan Pengemis di Pulau Jawa dilakukan untuk memahami diri sendiri dan orang lain melalui pembelajaran tentang keagamaan serta menumbuhkan cara berpikir positif dan keinginan untuk berprestasi. Kegiatan ini dilakukan untuk meningkatkan kemampuan gelandangan dan pengemis dalam melaksanakan ibadahnya. Adapun kegiatan yang dilakukan dalam bimbingan mental dan spiritual oleh kelima balai dalam penelitian ini adalah dengan mempraktikan kegiatan/ritual agama sesuai dengan kepercayaan masing-masing WBS seperti sholat, membaca Al'Quran, dan kegiatan keagamaan lainya.

Dapat disimpulkan bahwa bimbingan mental dan spiritual di Balai rehabilitasi sosial gelandangan dan pengemis di Pulau Jawa yang menurut teori disebutkan sebagai kegiatan untuk meningkatkan kemampuan gelandangan dan pengemis dalam melaksanakan ibadahnya ini sudah terlaksana walaupun dalam bimbingan mental dan spiritual tidak hanya dilakukan dengan kegiatan-kegiatan agama saja tetapi juga dengan kegiatan-kegiatan pembinaan mental lainnya guna merubah sikap dari WBS.

\section{e. Bimbingan Fisik}

Sebagaimana yang dikatakan dalam Dorang Luhpuri dan Rini Hartini R.A (2019), bimbingan fisik merupakan kegiatan untuk meningkatkan kesehatan fisik gelandangan dan pengemis melalui bimbingan kebugaran fisik, bimbingan aktivitas sehari-hari, dan bimbingan perawatan diri.

Berdasarkan hasil penelitian, bimbingan fisik di Balai Rehabilitasi Sosial Gelandangan dan Pengemis di Pulau Jawa dilaksanakan melalui kegiatan yang berkaitan dalam peningkatan kesehatan fisik seperti senam dan olahraga. Dalam menunjang kesehatan fisik WBS, kelima balai dalam penelitian ini juga menyediakan layanan pengasramaan dengan pemenuhan kebutuhan seperti makanan dan tempat tinggal yang layak pada setiap WBS serta layanan kesehatan beserta dengan tenaga kesehatan yang siap melayani saat WBS sakit.

Dapat disimpulkan bahwa bimbingan fisik di Balai Rehabilitasi Sosial Gelandangan dan Pengemis di Pulau Jawa yang menurut teori merupakan kegiatan untuk meningkatkan kesehatan fisik gelandangan dan pengemis melalui bimbingan kebugaran fisik, bimbingan aktivitas sehari-hari, dan bimbingan perawatan diri sudah terlaksana.

\section{f. Bimbingan Sosial dan Konseling Psikososial}

Sebagaimana yang dikatakan dalam Dalam Dorang Luhpuri dan Rini Hartini R.A (2019), bimbingan ini bertujuan untuk menumbuhkan, memelihara dan, mengembangkan kemampuan dalam relasi sosial dan interaksi sosial dengan lingkungan, melalui kegiatan seperti bimbingan keterampilan dalam berelasi dan berinteraksi dengan individu lainnya, keluarga dan masyarakat, selanjutnya bimbingan dalam meningkatkan kemampuan mengubah perilaku, menjalankan peran, memenuhi kebutuhan dan menyelesaikan masalah, serta bimbingan untuk meningkatkan pemahaman gelandangan dan pengemis tentang diri mereka sendiri, motif-motifnya, perasaan-perasaannya, reaksi-reaksinya dan sikap, perilakunya dalam kaitannya dengan lingkungannya.

Berdasarkan hasil penelitian, bimbingan sosial di Balai Rehabilitasi Sosial Gelandangan dan Pengemis di Pulau Jawa dilakukan untuk melatih kemampuan WBS dalam 
menumbuhkan kesadaran dan tanggung jawab sosial untuk menyesuaikan diri di masyarakat. Adapun kegiatan yang dilakukan pada bimbingan sosial merupakan kegiatan-kegiatan yang berkaitan dengan melatih kerjasama, dinamika kelompok, relasi, serta interaksi sosial WBS seperti outbond, kegiatan baris berbaris, kerja bakti, silaturahmi kemasyarakat pertemuan pagi, dan diskusi kelompok. Bimbingan ini bertujuan untuk menumbuhkan, memelihara dan, mengembangkan kemampuan dalam relasi sosial dan interaksi sosial WBS dengan lingkungannya serta untuk meningkatkan pemahaman gelandangan dan pengemis tentang diri sendiri dan perilakunya dalam kaitannya dengan lingkungannya.

Dapat disimpulkan bahwa bimbingan sosial dan konseling di Balai Rehabilitasi Sosial Gelandangan dan Pengemis di Pulau Jawa yang menurut teori merupakan bimbingan yang bertujuan untuk menumbuhkan, memelihara dan, mengembangkan kemampuan dalam relasi sosial dan interaksi sosial WBS dengan lingkungannya serta untuk meningkatkan pemahaman gelandangan dan pengemis tentang diri sendiri dan perilakunya dalam kaitannya dengan lingkungannya sudah terlaksana.

\section{g. Pelayanan Aksesibilitas}

Sebagaimana yang dikatakan dalam Dorang Luhpuri dan Rini Hartini R.A (2019), pelayanan aksesibilitas dilakukan untuk meningkatkan kemampuan klien dalam menjangkau layanan sosial yang dibutuhkan, ataupun menjangkau area dan sarana umum. Aksesibilitas terhadap lingkungan fisik dan non fisik, berupa sarana prasarana umum, jalan, gedung maupun teknologi layanan, informasi, dan terhadap fasilitas serta layanan lainnya.

Berdasarkan hasil penelitian, pelayanan aksesibilitas di Balai Rehabilitasi Sosial
Gelandangan dan Pengemis di Pulau Jawa dilakukan melalui penyediaan layanan-layanan yang salah satunya adalah layanan kesehatan pada sarana dan fasilitas umum salah satu contohnya adalah rumah sakit dan posyandu. Program ini dilakukan untuk meningkatkan kemampuan klien dalam menjangkau layanan sosial yang dibutuhkan, ataupun menjangkau area dan sarana umum yang tersedia.

Dapat disimpulkan bahwa pelayanan aksesibilitas di Balai Rehabilitasi Sosial Gelandangan dan Pengemis di Pulau Jawa yang menurut teori merupakan program yang dilakukan untuk meningkatkan kemampuan klien dalam menjangkau layanan sosial yang dibutuhkan, ataupun menjangkau area dan sarana umum sudah terlaksana.

\section{h. Bantuan dan Asistensi Sosial}

Sebagaimana yang dikatakan dalam Dorang Luhpuri dan Rini Hartini R.A (2019), bantuan dan asistensi sosial merupakan bantuan yang diberikan melalui bantuan pengembangan usaha mandiri. Asistensi sosial merupakan kegiatan untuk memberikan pendampingan terhadap klien dalam melakukan pengembangan usaha mandiri.

Berdasarkan hasil penelitian, bantuan dan asistensi sosial di Balai Rehabilitasi Sosial Gelandangan dan Pengemis di Pulau Jawa dilakukan melalui pemberian bantuan-bantuan dalam pengembangan usaha WBS baik berupa modal atau peralatan serta pendampingan kewirausahaan kepada WBS saat WBS sudah kembali kedalam masyarakat.

Dapat disimpulkan bahwa bantuan dan asistensi sosial di Balai Rehabilitasi Sosial Gelandangan dan Pengemis di Pulau Jawa yang menurut teori merupakan program pemberian bantuan melalui bantuan pengembangan usaha mandiri dan pendampingan terhadap klien 
dalam melakukan pengembangan usaha mandiri sudah terlaksana.

\section{i. Rujukan}

Sebagaimana yang dikatakan dalam Dorang Luhpuri dan Rini Hartini R.A (2019), rujukan merupakan kegiatan untuk memastikan bahwa klien mendapatkan layanan yang dibutuhkan untuk pengembangan dirinya, sedangkan layanan tersebut tidak dimiliki oleh lembaga pelayanan sebelumnya.

Berdasarkan hasil penelitian, rujukan di

Balai Rehabilitasi Sosial Gelandangan dan Pengemis di Pulau Jawa dilakukan melalui pengalihan layanan kepada pihak lain agar WBS memperoleh layanan lanjutan sesuai dengan kebutuhannya. Seperti yang diketahui bahwa pihak balai dapat merujuk WBS ke rumah sakit jika balai tidak memiliki layanan kesehatan yang memadai saat WBS sakit. Pihak balai juga merujuk para WBS kepada sektorsektor usaha sesuai dengan keterampilan yang dimiliki dan dipelajari di balai dengan tujuan agar WBS dapat bekerja dengan layak dan memperbaiki kualitas hidupnya.

Dapat disimpulkan bahwa rujukan di Balai Rehabilitasi Sosial Gelandangan dan Pengemis di Pulau Jawa yang menurut teori adalah kegiatan untuk memastikan bahwa WBS mendapatkan layanan yang dibutuhkan untuk pengembangan dirinya, sedangkan layanan tersebut tidak dimiliki oleh pihak balai sudah terlaksana.

\section{Faktor Pendukung Program Rehabilitasi} Sosial

a. Sebagaimana yang dikatakan dalam Subarsono (2005) bahwa "kondisi lingkungan sangat mempengaruhi implementasi kebijakan, yang dimaksud lingkungan ini mencakup lingkungan sosio kultural serta keterlibatan penerima program". Dalam Pasolong (2010) dikatakan juga bahwa salah satu faktor pendukung keberhasilan pelaksana adalah "hakikat kerja sama yang dibutuhkan, yaitu apakah semua pihak yang terlibat dalam kerja sama merupakan suatu assembling produktif". Berdasarkan hasil penelitian, beberapa WBS memiliki keinginan untuk berpartisipasi dan terlibat secara aktif serta dapat diajak kerja sama dalam melakukan program rehabilitasi. Hal ini ditunjukan melalui semangat dan keinginan WBS untuk menjadi lebih baik sehingga menjadi daya dorong beberapa dari mereka untuk menjalani program rehabilitasi sosial. Hal ini dapat dilihat juga dari perilaku beberapa WBS yang patuh dan memiliki rasa serta keinginan yang kuat untuk mau merubah dirinya dan berpartisipasi dalam setiap kegiatan yang dilaksanakan dalam rangka menunaikan tanggung jawab dan kewajibannya sebagai penerima layanan.

Dapat disimpulkan bahwa faktor lingkungan dan kerjasama dari berbagai pihak yang dalam hal ini adalah WBS sebagai penerima program dapat mendukung pelaksanaan dari program rehabilitasi sosial di Balai Rehabilitasi Sosial Gelandangan dan Pengemis di Pulau Jawa.

b. Sebagaimana yang dikatakan dalam Subarsono (2015) bahwa "hubungan antar organisasi dalam banyak program, implementasi sebuah program perlu dukungan dan koordinasi dengan instansi lain. Untuk itu diperlukan koordinasi dan kerjasama antar instansi bagi keberhasilan suatu program".

Berdasarkan hasil penelitian yang diuraikan dalam BRS Samekto Karti, BRSEGP Pangudi Luhur, dan PRSBK Cisarua bahwa terjalinnya kerjasama antara pihak balai 
dengan instansi terkait dapat membantu dalam pelaksanaan program. Contoh kerjasama yang dijalin seperti, pihak balai melakukan kerjasama dengan Dinas Sosial dan sektor-sektor usaha. Dinas sosial membantu pihak balai dalam mensosialisasikan program rehabilitasi sosial pada gelandangan dan pengemis dan membantu dalam berbagai proses rehabilitasi sosial yang dilakukan. Dunia usaha juga bekerja sama dengan pihak balai dengan menerima WBS dalam kegiatan magang bahkan menerima beberapa WBS ketika sudah selesai menjalani program rehabilitasi sosial untuk dipekerjakan. Selain itu, pihak balai juga dapat menjalin kerjasama dengan rumah sakit dan puskesmas setempat untuk pemenuhan kebutuhan WBS ketika sakit.

Dapat disimpulkan bahwa dengan terjalinnya relasi dan kerjasama yang baik antar organisasi atau instansi terkait dapat menjadi faktor yang mendukung dalam berjalannya program rehabilitasi sosial di Balai Rehabilitasi Sosial Gelandangan dan Pengemis di Pulau Jawa.

c. Sebagaimana yang dikatakan dalam Subarsono (2005), bahwa "sumber daya organisasi untuk implementasi program implementasi kebijakan perlu didukung sumber daya baik sumber daya manusia (human resources) maupun sumberdaya non-manusia (non human resources)". Dalam Pasolong (2010) dikatakan juga bahwa salah satu faktor pendukung pelaksanaan yaitu "Ketersediaan sumber daya manusia yang memiliki kemampuan, komitmen untuk mengelola pelaksanaanya". Berdasarkan hasil penelitian, diketahui bahwa tersedianya pekerja sosial sebagai SDM yang berkompeten dalam bidang kesejahteraan sosial sehingga dapat menjalankan pelayanan sosial yang baik menjadi salah satu faktor pendukung dalam program rehabilitasi sosial di balai. Seperti yang dikemukakan juga oleh BRS Samekto Karti Pemalang adanya buku penunjang yang digunakan dalam kegiatan pelayanan rehabilitasi sosial dapat menjadi faktor pendukung "non-manusia" dalam pelaksanaan program rehabilitasi sosial. BRSEGP Pangudi Luhur juga mengemukakan bahwa adanya bantuan dana dari Departemen Sosial RI, sarana dan prasana, dan instrumen sebagai alat dalam melaksanakan bimbingan lanjut dapat menjadi faktor pendukung "non-manusia" juga dalam berjalannya program rehabilitasi sosial. Sehingga dapat disimpulkan bahwa sumber daya manusia yang berkompeten dan sumber daya non-manusia yang memadai dapat menjadi faktor pendukung pelaksanaan program rehabilitasi sosial di Balai Rehabilitasi Sosial Gelandangan dan Pengemis di Pulau Jawa.

d. Sebagaimana yang dikatakan dalam Subarsono (2005), bahwa "karakteristik dan kemampuan agen pelaksana yang dimaksud karakteristik dan kemampuan agen pelaksana adalah mencakup struktur birokrasi, norma-norma, dan pola-pola hubungan yang terjadi dalam birokrasi, yang semuanya itu akan mempengaruhi implementasi suatu program". Dalam Pasolong (2010) dikatakan juga bahwa salah satu faktor pendukung keberhasilan pelaksana adalah "hakikat kerja sama yang dibutuhkan, yaitu apakah semua pihak yang terlibat dalam kerja sama merupakan suatu assembling produktif".

Berdasarkan hasil penelitian yang diuraikan dalam BRSEGP Pangudi Luhur bahwa 
pekerja sosial dan pegawai balai sebagai pengelola program mampu bekerjasama dan saling berkoordinasi dengan baik satu sama lain. Pegawai balai juga mau merangkap saat bertugas untuk membantu pegawai lain. Dapat disimpulkan bahwa kemampuan antar agen pelaksana untuk berkoordinasi dan bekerjasama dapat menjadi faktor pendukung dalam pelaksanaan program rehabilitasi sosial di Balai Rehabilitasi Sosial Gelandangan dan Pengemis di Pulau Jawa.

3. Faktor

Penghambat

Program

\section{Rehabilitasi Sosial}

a Sebagaimana yang dikatakan dalam Subarsono (2005) bahwa "kondisi lingkungan sangat mempengaruhi implementasi kebijakan, yang dimaksud lingkungan ini mencakup lingkungan sosio kultural serta keterlibatan penerima program". Dalam Pasolong (2010) dikatakan juga bahwa salah satu faktor penunjang keberhasilan pelaksana adalah "hakikat kerja sama yang dibutuhkan, yaitu apakah semua pihak yang terlibat dalam kerja sama merupakan suatu assembling produktif'.

Seperti yang dikemukakan oleh BRS Samekto Karti Pemalang, BRSEGP Pangudi Luhur, dan PRSBK Cisarua bahwa beberapa WBS malas dalam mengikuti kegiatan. Rasa malas ditunjukkan dengan kemauan dan kemampuan WBS yang rendah dalam mengikuti kegiatan rehabilitasi sosial seperti kegiatan pendidikan, bimbingan, kelas keterampilan dan lain sebagainya yang telah terjadwal di balai. Dalam PRSBK Cisarua dikemukakan juga bahwa WBS sulit untuk beradaptasi dengan lingkungan baru yaitu balai yang dituntut untuk patuh pada peraturan yang telah ditetapkan. Selain itu dalam BRSEGP Pangudi Luhur juga dijelaskan bahwa mental WBS dapat menjadi hambatan dalam program rehabilitasi sosial. Diketahui bahwa beberapa WBS masih malas-malasan ketika bekerja dan ditempatkan pada sektorsektor/dunia usaha, bahkan pulang tanpa pamit dan mengambil peralatan ditempat mereka bekerja. Hal ini mengurangi tingkat kepercayaan dunia usaha untuk mempekerjakan WBS dari balai sehingga berimbas kepada WBS yang lainnya. Beberapa WBS yang setelah dipulangkan dari balai juga memilih kembali menjadi gelandangan dan pengemis dan menjual bantuan peralatan yang telah diberikan, dengan alasan agar mereka mempunyai uang.

Dalam BRSEGP Pangudi Luhur dan BRS Mardi Utomo Semarang juga diuraikan bahwa faktor lain yang menjadi penghambat program yaitu sulitnya untuk mengajak masyarakat bekerja sama dengan kondisi lingkungan masyarakat yang menganggap bahwa penanganan masalah pengemis, gelandangan dan orang terlantar hanya menjadi tanggung jawab pemerintah, sehingga masyarakat merasa tidak perlu terlibat dalam proses penanganan. Sehingga dapat disimpulkan bahwa faktor lingkungan dan kerjasama yang tidak baik dari berbagai pihak yang dalam hal ini adalah masyarakat dan WBS sebagai penerima program dapat menjadi hambatan dalam pelaksanaan dari program rehabilitasi sosial di balai.

b. Sebagaimana yang dikatakan dalam Subarsono (2015) bahwa "sumber daya organisasi untuk implementasi program implementasi kebijakan perlu didukung sumber daya baik sumber daya manusia (human resources) maupun sumberdaya 
non-manusia (non human resources)". Hal ini juga dikatakan dalam Pasolong (2010) bahwa salah satu yang menjadi faktor penghambat pelaksanaan sebuah program adalah "ketidakmampuan SDM di bidang teknis dan administratif".

Berdasarkan hasil penelitian yang diuraikan dalam BRS Samekto Karti dan BRSEGP Pangudi Luhur diketahui bahwa anggaran serta sarana dan prasarana sebagai sumber daya "nonmanusia" (non human resources) yang dimiliki oleh beberapa balai belum memadai sehingga beberapa proses rehabilitasi sosial seperti bimbingan lanjut tidak terlaksana dengan baik, selain itu kegiatan bimbingan dalam program rehabilitasi khususnya bimbingan keterampilan yang dilaksanakan di beberapa balai juga tidak berjalan optimal. Diketahui juga dalam BRSEGP Pangudi Luhur bahwa balai belum memiliki instrumen yang baku dalam melakukan asesmen.

Selain sumber daya non-manusia (non human resources), sumber daya manusia (SDM) juga tidak kalah penting dalam terlaksananya sebuah program. Seperti yang diuraikan dalam BRSEGP Pangudi Luhur Bekasi bahwa belum semua petugas asesmen/pekerja sosial (sebagai SDM) memiliki keterampilan yang memadai dalam melakukan asesmen. Beberapa petugas asesmen atau pekerja sosial belum cermat dalam melakukan asesmen sehingga hasil asesmen kadang kala tidak sesuai dengan permasalahan yang dihadapi WBS. Dalam BRS Sidomulyo dijelaskan juga bahwa beberapa WBS terpaksa dalam mengikuti seluruh kelas keterampilan yang disediakan oleh balai dan dalam BRSEGP Pangudi Luhur juga menjelaskan bahwa beberapa WBS memilih jenis keterampilan yang tidak sesuai dengan kemampuannya sehingga terjadinya penumpukan WBS dalam satu jenis keterampilan dan menyebabkan kegiatan bimbingan berjalan kurang optimal. Maka dari itu pihak balai harus mampu mengidentifikasi dengan benar apa yang menjadi minat, bakat, serta kebutuhan dari masing-masing WBS. Maka dapat disimpulkan bahwa sumber daya manusia (human resources) dan non manusia (non-human resources) dapat menjadi faktor penghambat dalam program rehabilitasi sosial di Balai Rehabilitasi Sosial Gelandanangan dan Pengemis di Pulau Jawa jika tidak dikelola dengan baik.

c. Sebagaimana yang dikatakan dalam Pasolong (2010) bahwa salah satu hambatan dalam pelaksanaan program adalah "kelemahan institusi". Berdasarkan hasil penelitian yang diuraikan dalam BRSEGP Pangudi Luhur, diketahui bahwa ada beberapa eks WBS yang kesulitan untuk mencari sendiri pekerjaan dengan modal keterampilan yang dimiliki dari hasil bimbingan balai walaupun sudah menunjukan sertifikat dari balai, menurut eks WBS sertifikat yang didapat dari balai belum diakui oleh sektor-sektor usaha, sehingga pihak balai agaknya perlu memvalidasi sertifikat yang diberikan kepada WBS agar lebih diakui secara luas.

d. Sebagaimana yang dikatakan juga dalam Pasolong (2010) bahwa salah satu faktor penghambat dalam program dapat berasal dari "pengaturan waktu (timing)" yang tidak dikelola dengan baik. Seperti yang 
dijelaskan dalam BRSEGP Pangudi Luhur bahwa jangka waktu pelayanan di balai dirasa cukup singkat yaitu kurang lebih 6 bulan, sehingga proses pelayanan yang diberikan kurang maksimal dan banyak WBS yang kembali lagi mengemis dan menggelandang setelah selesainya proses pelayanan yang diberikan oleh balai dengan asumsi untuk mengubah sikap normatif dari gelandangan dan pengemis tidaklah mudah dan membutuhkan waktu yang lama. Dalam BRSBK Sidomulyo diketahui juga bahwa beberapa WBS mengeluhkan mengenai durasi waktu dalam kegiatan bimbingan keterampilan yang hanya dilakukan 45 menit. Menurut mereka bahwa durasi tersebut cukup singkat. Maka dapat disimpulkan bahwa pengelolaan waktu yang baik cukup penting dalam pelaksanaan program rehabilitasi sosial di Balai Gelandangan dan Pengemis di Pulau Jawa.

\section{KESIMPULAN}

Berdasarkan hasil penelitian yang diperoleh dari analisis data sekunder di lima lokasi Balai Rehabilitasi Sosial Gelandangan dan Pengemis di Pulau Jawa, antara lain: Balai Rehabilitasi Sosial Bina Karya (BRSBK) Sidomulyo Yogyakarta, 2) Balai Rehabilitasi Sosial (BRS) Mardi Utomo Semarang, 3) Balai Rehabilitasi Sosial Samekto Karti Pemalang, 4) Panti Rehabilitasi Sosial Bina Karya Cisarua Bandung Barat. 5) Balai Rehabilitasi Sosial Eks Gelandangan dan Pengemis (BRSEGP) Pangudi Luhur Bekasi, diketahui bahwa pelaksanaan program rehabilitasi sosial sudah dilaksanakan sebagaimana mestinya dengan beberapa faktor-faktor yang menjadi pendukung dan penghambat didalamnya.

Dalam pelaksanaannya, program rehabilitasi sosial dilakukan melalui beberapa proses tahapan. Hasil penelitian menunjukan bahwa secara garis besar proses rehabilitasi sosial yang dilaksanakan di balai rehabilitasi sosial gelandangan dan pengemis di lima lokasi penelitian yang tersebar di Pulau Jawa relatif sama dimulai dari pendekatan awal, penerimaan, assesment, penyusunan program penanganan, pelaksanaan program rehabilitasi sosial, resosialisasi, bimbingan lanjut, dan terminasi. Hal ini dikarenakan program rehabilitasi di balai rehabilitasi sosial gelandangan dan pengemis merupakan upaya dan wujud nyata dari pemerintah dalam menangani permasalahan gelandangan dan pengemis, sehingga kebijakan dasar yang digunakan tiap balai dalam penelitian ini merupakan kebijakan yang sama yaitu kebijakan pemerintah dalam penanganan gelandangan dan pengemis. Diketahui juga bahwa proses rehabilitasi sosial yang dilakukan oleh kelima balai dalam penelitian ini sudah dilaksanakan sebagaimana mestinya walaupun ada beberapa hambatan dalam pelaksanannya. Dapat dilihat juga bahwa pemerintah telah melakukan upaya seoptimal mungkin dalam penganganan gelandangan dan pengemis. Hal ini dapat dilihat dari uraian proses yang dilaksanakan tiap balai cukup sistematis dan terorganisir dengan baik serta sesuai dengan kebijakan, walaupun ada beberapa hambatan yang terjadi namun pihak balai tetap dapat melaksanakan dan menyelesaikan proses pertolongannya kepada warga binaan sosial (WBS).

Dalam mengkaji pelaksanaan progam rehabilitasi sosial dilihat juga dari jenis program rehabilitasi sosial yang dilaksanakan. Hasil penelitian menunjukkan bahwa jenis program rehabilitasi sosial yang dilakukan pada balai dalam penelitian ini sudah terlaksana dan sesuai dengan kebutuhan WBS 
walaupun ditemukan juga beberapa hambatan serta kekurangan dalam pelaksanaanya. Serupa dengan proses rehabilitasi sosial, secara garis besar tiap balai dalam penelitian ini juga memiliki jenis program pelayanan yang relatif sama satu sama lain, walaupun dalam bentuk kegiatannya akan menyesuaikan dengan kondisi dan kebijakan dari masing-masing balai. Program yang dilaksanakan di balai juga sangat diupayakan untuk mencakup aspekaspek kebutuhan dari diri klien seperti mental dan spiritual, sosial, fisik, dan keterampilan. Selain itu, pihak balai juga sangat berupaya untuk memperhatikan kebutuhan sandang, pangan, serta papan yang layak bagi klien selama menjalani program rehabilitasi.

Dalam mengkaji pelaksanaan program rehabilitasi sosial terdapat juga beberapa faktor yang menjadi pendukung program tersebut agar berjalan optimal. Adapun faktor pendukung dari program rehabilitasi sosial di Balai Rehabilitasi Sosial Gelandangan dan Pengemis di Pulau Jawa, yaitu:

1 Warga Binaan Sosial (WBS) mau berpartisipasi dan terlibat serta dapat diajak kerja sama dalam kegiatan program rehabilitasi sosial. Dapat dilihat dari perilaku beberapa WBS yang patuh dan berpartisipasi dalam setiap kegiatan yang dilaksanakan dalam rangka menunaikan tanggung jawab dan kewajibannya sebagai penerima layanan

2 Adanya kerjasama antara pihak balai dengan instansi terkait seperti Dinas Sosial, dunia usaha, dan instansi lainnya dalam penanganan gelandangan dan pengemis.

3 Tersedianya Pekerja Sosial (Peksos) yang berkompeten dalam bidang kesejahteraan sosial sehingga dapat menjalankan pelayanan sosial yang baik.
4 Pekerja sosial dan pegawai balai sebagai pengelola program mampu bekerjasama dan saling berkoordinasi dengan baik satu sama lain.

5 Adanya buku penunjang dan instrumen lainnya yang dapat membantu dalam program rehabilitasi sosial.

Adapun dalam penelitian ini ditemukanz juga faktor penghambat dari program rehabilitasi sosial di Balai Rehabilitasi Sosial Gelandangan dan Pengemis di Pulau Jawa, yaitu:

1 Warga Binaan Sosial (WBS) memiliki mental dan perilaku yang malas dalam mengikuti program rehabilitasi sosial di balai.

2 WBS sulit untuk beradaptasi dengan lingkungan balai yang dituntut untuk patuh pada peraturan yang telah ditetapkan.

3 Dana, sarana, dan prasarana yang belum memadai.

4 Masyarakat yang sulit diajak kerjasama dan menganggap bahwa penanganan masalah gelandangan dan pengemis hanya menjadi tanggung jawab pemerintah.

5 Sertifikat dari balai yang belum diakui oleh sektor-sektor usaha sehingga WBS sulit mencari pekerjaan dengan sertifikat yang didapat.

6 Belum semua petugas asesmen/pekerja sosial memiliki keterampilan yang memadai dalam melakukan asesmen dan belum tersedianya instrumen baku untuk melakukan asesmen di beberapa balai.

7 Pengelolaan waktu yang kurang optimal dalam program rehabilitasi sosial.

Maka dengan dilakukannya penelitian ini diharapkan kepada pihak balai mampu memaksimalkan tingkat pelayanannya kepada WBS, sehingga balai rehabilitasi sosial gelandangan dan pengemis sebagai salah satu 
penyelenggara kesejahteraan sosial diharapkan mampu:

1 Melakukan pengelolaan dana yang baik sehingga semua program yang diadakan dapat dilaksanakan dengan baik.

2 Memaksimalkan kemampuan pihak pelaksana program rehabilitasi sosial seperti pegawai, instruktur, dan khususnya pekerja sosial pekerja sosial, maka perlu mengikutsertakan dalam pelatihan dan diklat.

3 Memperhatikan juga sarana dan prasarana yang kurang memadai guna menunjang program agar berjalan dengan baik.

4 Memiliki jalan keluar (alternatif lain) jika ada hambatan dalam pelaksanaan program atau salah satu program di balai tidak terlaksana dengan baik.

Peneliti juga berharap agar hasil penelitian ini dapat digunakan sebagai salah satu referensi untuk penelitian selanjutnya dengan metode dan pendekatan penelitian yang berbeda sehingga akan memperoleh hasil yang lebih mendalam dari aspek yang dibahas dalam penelitian ini.

\section{DAFTAR PUSTAKA}

AG Subarsono. (2005). Analisis Kebijakan Publik Konsep, Teori dan Aplikasi. Yogyakarta: Pustaka Pelajar.

Dorang Luhpuri dan Rini Hartini R.A. (2019). Disabilitas: Pengenalan dan Praktik Pekerjaan Sosial dengan Disabilitas di Indonesia. Bandung: POLTEKESOS Press.

Nitimihardja. (2004). Rehabilitasi Sosial dalam Jaminan Sosial (Isu-Isu Tematik Pembangunan Sosial Konsepsi dan Strategi). Jakarta: Balatbangsos.

Pasolong Harbani. (2010). Teori Administrasi Publik, Alfabeta, Bandung.

Peraturan Menteri Sosial No 16 tahun 2019 tentang Standar Nasional Rehabilitasi Sosial.

Sugiyono. (2017). Metode Penelitian
Pendidikan Pendekatan Kuantitatif, Kualitatif, $R \& D$. Bandung: Alfabeta.

Tatang M. Amirin. (2015). Metode Penelitian Sekunder (Analisis Data Sekunder). Yogyakarta: Universitas Negeri Yogyakarta (Tatang M. Amirin Blog).

\section{Sumber Analisis Data Sekunder:}

Alvi Rochmah Dewi. (2019). Peran Unit Pelaksana Teknis Daerah (UPTD) Panti Rehabilitasi Sosial Bina Karya Dalam Pemberdayaan Komunitas Gelandangan dan Pengemis. Universitas Islam Negeri Sunan Gunung Djati Bandung.

Balai Rehabilitasi Sosial Bina Karya Sidomulyo Yogyakarta. Standar Operasional Prosedur. Diakses dari http://brsbkl.jogjaprov.go.id/.

Balai Rehabilitasi Sosial Eks Gelandangan dan Pengemis. Standar Operasional Prosedur Diakses dari https://pangudiluhur.kemsos.go.id/.

Balai Rehabilitasi Sosial Mardi Utomo Semarang. Standar Operasional Prosedur. Diakses dari http://mardiutomosemarang.blogspot.com/p /pengantar.html.

Balai Rehabilitasi Sosial Samekto Karti Pemalang. Standar Operasional Prosedur. Diakses dari http://samektokartipemalang.blogspot.com/ p/sop-balai-rehabilitasi-sosial-pgoteks.html

Muhammad Akmal. (2009). Pelayanan Sosial bagi Gelandangan dan Pengemis di Panti Sosial Bina Karya Pangudi Luhur Bekasi. Universitas Islam Negeri Syarif Hidayatullah Jakarta.

Rayanis Maria Ulfa. Program Pelayanan dan Rehabilitasi Sosial Bagi Pengemis, Gelandangan, dan Orang Telantar di balai rehabilitasi sosial Mardi Utomo Semarang Tahun 2011-2014. Universitas Diponegoro Semarang.

Rizky Dwitanto Putro. (2015). Pembinaan Pengemis, Gelandangan, dan Orang Terlantar di Balai Rehabilitasi Sosial Samekto Karti Pemalang. Universitas Negeri Semarang.

Ruaida Murni. (2014). Pelayanan dan 
Rehabilitasi Sosial terhadap Gelandangan dan Pengemis di Panti Sosial Bina Karya Pangudi Luhur Bekasi. Pusat Penelitian dan Pengembangan Kesejahteraan Sosial, Kementrian Sosial RI.

Tri Muryani. (2008). Rehabilitasi Sosial Bagi Gelandangan di Panti Sosial Bina Karya Sidomulyo Yogyakarta. Universitas Islam Negeri Sunan Kalijaga Yogyakarta. 